\title{
PEMENUHAN HAK ATAS PERUMAHAN YANG LAYAK HUNI BAGI KORBAN PENGGUSURAN MEDOKAN SEMAMPIR KOTA SURABAYA BERDASARKAN RIGHT TO THE CITY
}

\author{
Rizka Elvira Putri ${ }^{1}$, Ucu Martanto $^{2}$ \\ ${ }^{1}$ Departemen Ilmu Politik, Fakultas Ilmu Sosial dan Ilmu Politik, Universitas Airlangga \\ rizkaelvira1997@gmail.com \\ ${ }^{2}$ Departemen Ilmu Politik, Fakultas Ilmu Sosial dan Ilmu Politik, Universitas Airlangga \\ ucu.martanto@fisip.unair.ac.id
}

\begin{abstract}
Abstrak: Penelitian ini membahas tentang upaya Pemerintah Kota Surabaya dalam memenuhi hak atas perumahan yang layak huni khususnya bagi masyarakat miskin yang terkena dampak dari program Pemerintah Kota Surabaya salah satunya yaitu akibat penggusuran yang berada di Kelurahan Medokan Semampir Kota Surabaya. Fokus penelitian ini adalah untuk mengetahui program-program apa saja serta solusi apa saja yang telah dilakukan oleh Pemerintah Kota Surabaya dalam memenuhi hak atas perumahan layak untuk masyarakat yang terkena dampak dari penggusuran. Penelitian ini menggunakan teori right to the city dari Henry Levebfre untuk menganalisis pembangunan Kota Surabaya bahwa masyarakat kota memiliki hak atas pembangunan kotanya sendiri. Penelitian ini menggunakan pendekatan kualitatif dengan metode deskriptif analisis untuk menganalisis serta menggambarkan suatu masalah yang ada di lapangan. Pengambilan data didapatkan menggunakan metode purposive sampling di mana penulis sudah menentukan subjek penelitian dengan berdasarkan ciri-ciri khusus yang sesuai dengan permasalahan penelitian. Hasil dari penelitian ini adalah upaya Pemerintah Kota Surabaya dalam memenuhi hak atas perumahan layak huni bagi masyarakat miskin khususnya masyarakat korban dari penggusuran, Kendala Pemerintah Kota Surabaya dalam memenuhi hak atas perumahan layak huni untuk masyarakat miskin Kota Surabaya, Penolakan Warga Medokan atas ganti rugi yang telah ditawarkan oleh Pemerintah Kota Surabaya, Dampak dari adanya kebijakan maupun program Pemerintah Kota Surabaya terhadap pemenuhan perumahan yang layak huni untuk masyarakat miskin. Kesimpulan dari penelitian ini adalah pemenuhan hak atas perumahan layak bagi masyarakat miskin khususnya korban penggusuran Medokan Semampir Kota Surabaya tidak berjalan dengan baik karena pada saat program penggusuran terjadi masyarakat korban dari penggusuran belum ditempatkan pada tempat yang baik.
\end{abstract}

Kata Kunci: Hak atas pembangunan, perumahan rakyat, kemiskinan perkotaan, pembangunan perumahan.

\section{PENDAHULUAN}

Masyarakat berpenghasilan rendah sering kali tidak mampu memenuhi kebutuhan tempat tinggalnya dengan baik karena faktor keterbatasan biaya. Dalam hal ini Pemerintah Kota Surabaya melakukan upaya pemenuhan hak atas perumahan yang layak khususnya bagi masyarakat miskin agar kebutuhan rumah yang layak huni dan sehat di Kota Surabaya dapat terpenuhi dengan baik serta dapat mengurangi angka backlog di Kota Surabaya setiap tahunnya. Pemenuhan hak atas perumahan layak yang dilakukan oleh Pemerintah Kota Surabaya salah satunya yaitu untuk mewujudkan pembangunan rumah yang bersih dan sehat yang dilengkapi dengan sarana dan prasarana memadai. Kota Surabaya memiliki jumlah penduduk yang padat namun dalam kepadatan jumlah penduduk tersebut tidak seimbang dengan tersedianya jumlah lahan kosong sehingga menyebabkan banyak timbulnya kawasan permukiman kumuh di Kota Surabaya. Dalam hal ini pemenuhan hak atas perumahan layak telah diatur pada Undang-Undang Dasar 1945 pasal 28H ayat 1 yang menyatakan bahwa setiap orang berhak untuk hidup sejahtera lahir batin, memiliki tempat tinggal dan mendapatkan lingkungan yang baik sehat serta mendapatkan pelayanan kesehatan. 
Pemenuhan hak atas perumahan layak telah dilakukan oleh Pemerintah Kota Surabaya khususnya bagi masyarakat miskin yang masih tinggal di kawasan permukiman kumuh seperti yang terjadi di kelurahan Medokan Semampir Kota Surabaya. Dahulu harga tanah di daerah tersebut terbilang sangat murah mengakibatkan banyak penduduk Kota Surabaya yang membeli di daerah tersebut tanpa adanya alas kepemilikan dan sertifikat, namun setelah beberapa tahun kemudian rumah penduduk tersebut digusur oleh Pemerintah Kota Surabaya karena bangunan rumah dianggap sebagai bangunan liar karena tidak memiliki alas kepemilikan dan salah satu penyebabnya yaitu adanya dari program Pemerintah Kota Surabaya yang dinamakan program Pengentasan Kawasan Prioritas. Program pengentasan kawasan prioritas tersebut diadakan karena adanya program revitalisasi sungai Brantas yang mengharuskan tempat tinggal warga untuk digusur.

Warga menolak dengan adanya program Pemerintah Kota Surabaya tersebut karena mereka tidak menyetujui dengan kebijakan Pemerintah tentang program revitalisasi sungai. Masyarakat ingin diberikan negosiasi hingga permasalahan penggusuran tersebut menemukan solusi yang tepat bagi masyarakat tidak menguntungkan salah satu pihak saja (Harvey, 2012). Namun pemerintah tidak menghiraukan hal tersebut hingga penggusuran telah dilakukan oleh Pemerintah Kota Surabaya karena dianggap tanah tersebut bukan milik warga melainkan milik Dinas Pekerja Umum Pengairan. Dalam penggusuran tersebut masyarakat Medokan banyak yang menolak karena keputusan tersebut dianggap tidak melibatkan masyarakat sehingga masyarakat yang digusur tetap mempertahankan tanahnya untuk bisa kembali sebagai bentuk protes kepada Pemerintah Kota Surabaya.

Bentuk protes masyarakat terhadap Pemerintah Kota Surabaya ditandai dengan masyarakat membangun bangunan liar lagi di sekitar kawasan tanah mereka yang digusur karena mereka tidak setuju dengan pembangunan kota yang bersifat neoliberalisme (Levebfre, 1967). Masyarakat membangun bangunan liar lagi di sekitar tanah mereka yang digusur merupakan tanggung jawab dari negara, dalam hal ini tanggung jawab negara akan menjadi lebih berat lagi karena masyarakat tidak mengambil fasilitas dari Pemerintah Kota Surabaya yang telah diberikan berupa rumah susun sewa.

Rumah susun sewa merupakan fasilitas dari Pemerintah Kota Surabaya yang diberikan kepada masyarakat miskin namun yang diutamakan dalam rusunawa tersebut yaitu masyarakat yang menjadi korban dari penggusuran karena mereka kehilangan tempat tinggalnya. Masyarakat menolak dengan fasilitas yang diberikan oleh Pemerintah Kota Surabaya karena jarak rusunawa dengan tempat tinggal mereka yang dulu cukup jauh sehingga mereka menolak fasilitas yang diberikan Pemerintah Kota Surabaya. Masyarakat lebih memilih tinggal di jalanan sekitar tanah mereka yang sudah digusur dengan bangunan seadanya secara tidak layak.

Masyarakat tidak hanya menolak berupa fasilitas yang diberikan oleh Pemerintah Kota Surabaya saja namun mereka juga menolak ganti rugi yang telah ditawarkan oleh Pemerintah karena menurut masyarakat Medokan ganti rugi tersebut tidak sesuai dengan yang diharapkan. Masyarakat merasa tidak dilibatkan dalam proses pembangunan kota maupun proses pembuatan kebijakan yang telah dibuat dari Pemerintah Kota Surabaya tersebut (Levebfre, 1967). Pemerintah Kota Surabaya 
dianggap tidak menemukan solusi dalam permasalahan penggusuran tersebut karena negosiasi antara Pemerintah bersama masyarakat Medokan tidak disetujui oleh pihak warga. Hingga penggusuran tersebut telah dilakukan namun masyarakat korban dari penggusuran masih tinggal di jalanan selama bertahun-tahun karena tidak mengambil fasilitas yang diberikan oleh Pemerintah Kota Surabaya dengan alasan berbagai macam faktor.

Pemenuhan hak atas perumahan layak huni telah diatur pada Undang-Undang Dasar 1945 hal tersebut merupakan tanggung jawab dari negara untuk dapat memenuhi tempat tinggal rakyat secara layak. Dalam hal pemenuhan perumahan layak huni Pemerintah Kota Surabaya mengalami beberapa macam kendala yang telah dilakukan dan dampak yang terjadi setelah program dari Pemerintah Kota Surabaya sudah dilaksanakan. Maka dari permasalahan yang telah disebutkan pada sebelumnya dapat ditarik suatu rumusan masalah yaitu, bagaimana upaya Pemerintah Kota Surabaya terhadap pemenuhan hak atas perumahan yang layak bagi masyarakat miskin, bagaimana dampak dari kebijakan Pemerintah Kota Surabaya terhadap pemenuhan perumahan layak huni untuk masyarakat miskin, apakah upaya Pemerintah Kota Surabaya dalam memenuhi hak atas perumahan yang layak bagi korban penggusuran sudah berjalan dengan baik.

Penelitian ini menggunakan pendekatan kualitatif dengan metode deskriptif analisis karena dirasa sesuai dengan tujuan yang ingin dicapai oleh peneliti untuk menjelaskan dan menggambarkan upaya pemenuhan Pemerintah Kota Surabaya dalam memenuhi hak atas perumahan yang layak huni bagi korban penggusuran di Kota Surabaya. Penelitian ini menggunakan Teori right to the city dari Henry Levebfre untuk melihat pembangunan di Kota Surabaya apakah telah melibatkan masyarakat yang ada di kota tersebut khususnya bagi masyarakat yang terkena dampak dari kebijakan Pemerintah Kota Surabaya. Pembangunan kota perlu melibatkan masyarakat yang berada dalam perkotaan tersebut. Hak atas kota tidak semata-mata masyarakat bisa mengakses sumber daya yang ada dalam perkotaan tersebut melainkan masyarakat juga memiliki hak untuk mengubah diri seseorang tersebut untuk dapat mengubah kotanya (Levebfre, 1967). Kota juga dipandang sebagai tempat tinggal paling buruk oleh masyarakat namun pada nyatanya kota dapat melewati berbagai macam permasalahan yang ada di dalam kota tersebut.

Tolak ukur pada right to the city yaitu tentang hak atas kota keikutsertaan rakyat atau partisipasi dari rakyat untuk dapat membangun kotanya sendiri (Levebfre, 1967). Partisipasi yang bersifat kolektif dalam pembangunan kota tidak hanya dilakukan oleh seseorang individu maupun dari kelompok tertentu saja melainkan harus melibatkan seluruh masyarakat yang ada di dalam perkotaan tersebut (Harvey, 2012). Tidak hanya partisipasi kolektif dari masyarakat untuk membangun kotanya saja right to the city juga sebagai bentuk perlawanan dalam melawan pembangunan kota yang bersifat neoliberalisme seperti komersialisasi, privatisasi lahan, dominasi kawasan industri maupun perdagangan. Partisipasi tersebut muncul dari kesadaran masyarakat yang itu sendiri dalam membangun kotanya untuk bisa menjadi lebih baik. 
Pada sebuah proses pembangunan perkotaan yang tidak melibatkan masyarakat dalam hal proses pembuatan kebijakan maupun program yang dilakukan oleh Pemerintah Kota Surabaya mengakibatkan timbul pembangunan yang dinamakan restrukturasi urban yang biasa disebut dengan penggusuran. Penggusuran tersebut jika dilihat dalam perspektif right to the city merupakan bentuk penghancuran secara halus akibat dengan adanya dimensi kelas karena masyarakat miskin kalangan menengah ke bawah tidak memiliki kedudukan dan terbungkam sehingga masyarakat miskin menengah ke bawah semakin terpinggirkan yang disebabkan oleh kekuatan politik (Levebfre, 1967).

Fokus penelitian ini mengenai tentang upaya yang dilakukan oleh Pemerintah Kota Surabaya dalam memenuhi hak atas perumahan yang layak khususnya bagi masyarakat korban dari penggusuran berdasarkan pada perspektif Right to the city apakah sudah berjalan dengan baik. Sedangkan dalam penelitian ini menggunakan teknik pengumpulan data dengan melalui wawancara dan observasi.

\section{UPAYA PEMERINTAH KOTA SURABAYA DALAM MEMENUHI HAK ATAS PERUMAHAN}

Pemerintah Kota Surabaya memiliki berbagai macam program maupun kebijakan dalam memenuhi hak atas perumahan yang layak khususnya bagi masyarakat miskin di Kota Surabaya yang tidak mampu memenuhi kebutuhan tempat tinggalnya dengan baik. Pemerintah Kota Surabaya membuat beberapa macam program salah satunya yaitu membangun rusunawa yang dikhususkan untuk masyarakat tidak mampu namun seiring berjalannya waktu rusunawa tersebut kini berganti lebih difokuskan untuk masyarakat korban dari penggusuran. Penggusuran tersebut merupakan program dari Pemerintah Kota Surabaya yang dilakukan untuk mengatasi kawasan permukiman kumuh di Kota Surabaya seperti yang terjadi di Kelurahan Medokan Semampir Kota Surabaya. Upaya Pemerintah Kota Surabaya dalam memenuhi hak atas perumahan mereka telah membangun beberapa unit rusunawa yang tersebar di Kota Surabaya dan setiap tahunnya mereka terus membangun rusunawa baru karena dikhususkan bagi masyarakat yang tidak memiliki tempat tinggal karena adanya program penggusuran dari Pemerintah Kota Surabaya. Berikut beberapa macam rusunawa yang telah dibangun oleh Pemerintah Kota Surabaya hingga saat ini tahun 2019.

Tabel 1. Daftar Rusunawa di Kota Surabaya

\begin{tabular}{|c|l|l|c|c|c|}
\hline No & \multicolumn{1}{|c|}{ Nama Rusun } & \multicolumn{1}{|c|}{ Alamat Rusun } & Blok & Lantai & Unit \\
\hline 1 & Urip Sumoharjo & Jl.Urip Sumoharjo & 3 & 4 & 120 \\
\hline 2 & Sombo & Jl.Sombo Kel. Simolawang & 10 & 4 & 600 \\
\hline 3 & Dupak Bangunrejo & Jl.Dupak Bangunsari Kel. Dupak Kec. Krembangan & 6 & 3 & 150 \\
\hline 4 & Penjaringansari I & Jl.Penjaringansari Timur Kec. Rungkut & 3 & 2 & 20 \\
\hline 5 & Waru Gunung & Jl.Mastrip Kec.Karangpilang & 10 & 5 & 600 \\
\hline 6 & Penjaringansari II & Jl.Penjaringansari Timur Kec. Rungkut & 6 & 4 & 200 \\
\hline 7 & Penjaringansari III & Jl.Penjaringansari Kel.Penjaringansari Kec.Rungut & 2 & 5 & 99 \\
\hline 8 & Wonorejo I & Jl.Wonorejo Kel.Wonorejo Kec.Rungkut & 2 & 4 & 96 \\
\hline
\end{tabular}




\begin{tabular}{|c|l|l|c|c|c|}
\hline 9 & Wonorejo II & Jl.Wonorejo Kel.Wonorejo Kec.Rungkut & 4 & 4 & 192 \\
\hline 10 & Tanah Merah I & Jl.Tanah Merah Kel.Kedinding Kec.Kenjeran & 4 & 5 & 192 \\
\hline 11 & Tanah Merah II & Jl.Tanah Merah Kel.Kedinding Kec.Kenjeran & 4 & 5 & 196 \\
\hline 12 & Randu & Jl.Randu Agung Kel.Sidotopo Wetan Kec.Kenjeran & 6 & 5 & 288 \\
\hline 13 & Grudo & Jl.Grudo V/2 Kel.Dr Soetomo Kec.Tegalsari & 2 & 5 & 99 \\
\hline 14 & Pesapen & Jl.Pesapen Selatan no.27 Kel.Krembangan Selatan & 1 & 5 & 49 \\
\hline 15 & Jambangan & Jl.Jambangan Kel.Jambangan & 1 & 5 & 49 \\
\hline 16 & Siwalankerto & Kel.Siwalankerto Kec.Wonocolo & 2 & 5 & 99 \\
\hline 17 & Romokalisari & Kel.Romokalisari Kec.Benowo & 10 & 5 & 495 \\
\hline 18 & Bandarejo & Kel. Sememi Kec. Benowo & 2 & 5 & 99 \\
\hline
\end{tabular}

Pemerintah Kota Surabaya juga memiliki program pengentasan kawasan prioritas untuk mengurangi kawasan permukiman kumuh yang berada di Kota Surabaya agar masyarakat bisa memenuhi kebutuhan rumah yang bersih dan sehat berdasarkan konsep rumah layak huni. Namun masyarakat tidak setuju dengan program Pemerintah yang telah dilaksanakan karena mereka kehilangan tempat tinggalnya. Pemerintah Kota Surabaya memiliki program pengentasan kawasan prioritas agar masyarakat memiliki lingkungan sanitasi yang sehat dan tidak perlu lagi mengeluarkan biaya untuk berobat ke rumah sakit dalam hal ini program pengentasan kawasan prioritas juga untuk mengurangi angka kemiskinan dan bencana banjir yang terjadi di Kota Surabaya. Berdasarkan teori right to the city pengertian kota merupakan dianggap tempat tinggal yang paling buruk oleh masyarakat namun kota juga dapat melewati sendiri segala permasalahannya. Kota Surabaya banyak kawasan permukiman kumuh namun masyarakat mengaku bersedia jika memperbaiki kawasan tersebut dalam hal ini masyarakat bersedia memperbaiki asalkan tempat tinggal mereka tidak dimusnahkan begitu saja namun Pemerintah tidak mau tahu akan hal tersebut.

\section{PENOLAKAN TERHADAP NEOLIBERALISME}

Masyarakat tidak menyetujui dengan adanya program Pemerintah Kota Surabaya salah satunya program pengentasan kawasan prioritas. Masyarakat setuju dengan adanya program Pemerintah untuk mengurangi kawasan permukiman kumuh di Kota Surabaya namun mereka tidak setuju jika tempat tinggal mereka dimusnahkan begitu saja. Pengentasan kawasan prioritas ditandai dengan adanya penggusuran tempat tinggal masyarakat yang dianggap tidak layak huni setelah penggusuran tersebut dilakukan akan dibangun pembangunan perumahan yang baru oleh developer. Masyarakat yang telah digusur rumahnya tetap mempertahankan tanahnya untuk bisa kembali dengan cara mereka membangun bangunan liar lagi di sekitar tanah mereka yang telah digusur.

Masyarakat yang membangun bangunan liar lagi di sekitar tanah mereka merupakan sebagai bentuk protes kepada Pemerintah Kota Surabaya terhadap pembangunan kota yang bersifat neoliberalisme. Sejalan dengan teori right to the city bahwa adanya penolakan terhadap neoliberalisme ini dilakukan oleh masyarakat korban penggusuran di Kelurahan Medokan Semampir yang telah 
kehilangan tempat tinggalnya. Mereka menetap di sekitar tanah mereka selama bertahun-tahun mendirikan bangunan liar lagi di jalan karena mereka tidak ingin tanah mereka yang telah digusur dibangun oleh Pemerintah yang bersifat neoliberalisme seperti privatisasi lahan, pendominasian industri perdagangan dan pembangunan lainnya. Hingga sampai saat ini masyarakat tidak mau mengambil fasilitas yang diberikan oleh Pemerintah Kota Surabaya berupa rumah susun sewa mereka lebih memilih menetap di sekitar tanah mereka yang telah digusur selama bertahun-tahun dalam kondisi sangat tidak layak jauh lebih buruk dari tempat tinggal mereka yang sebelumnya.

Bagi mereka kawasan permukiman kumuh masih bisa diperbaiki tanpa harus memusnahkan begitu saja tanpa adanya negosiasi sepakat antara kedua belah pihak tidak hanya menguntungkan salah satu pihak saja. Masyarakat tidak ingin bekas tanah mereka yang dahulu tempati dibangun oleh pihak swasta untuk pembangunan rumah baru atau perumahan. Mereka lebih memilih untuk menetap di sekitar tanah mereka dengan bangunan seadanya daripada harus menempati rumah susun sewa yang diberikan fasilitas oleh Pemerintah Kota Surabaya.

Banyak faktor alasan masyarakat tidak mengambil fasilitas yang diberikan Pemerintah Kota Surabaya salah satunya mereka menolak adanya pembangunan kota yang bersifat neoliberalisme. Faktor lain yaitu ganti rugi yang diberikan tidak sesuai karena masyarakat merasa dirugikan dengan adanya program dari Pemerintah Kota Surabaya dan fasilitas yang diberikan berupa rusunawa tersebut jaraknya sangat jauh dari tempat tinggal mereka yang dahulu sehingga masyarakat keberatan dengan fasilitas yang diberikan karena jika mereka pindah akan kehilangan segalanya termasuk pendidikan untuk anak mereka, mata pencaharian, serta kehidupan sosial lain yang telah dibangun berpuluh-puluh tahun lamanya.

Aksi protes yang dilakukan masyarakat korban penggusuran di Medokan Semampir merupakan tanggung jawab dari negara karena pada Undang-Undang Dasar 1945 pasal 28H ayat 1 sudah tertulis jelas bahwa masyarakat berhak mendapatkan tempat tinggal yang layak dan hal ini merupakan tanggung jawab dari negara, negara harus memenuhi hak masyarakat tersebut. Hal ini sejalan dengan pemikiran. Hal ini sejalan dengan teori right to the city bahwa masyarakat tidak hanya bisa mengakses sumber daya yang ada di perkotaan melainkan mereka juga mempunyai hak untuk bisa mengubah kotanya sendiri untuk bia menjadi kota yang lebih baik (Levebfre, 1967).

Penggusuran yang terjadi di Medokan Semampir Kota Surabaya telah melanggar hak dari masyarakat karena Pemerintah Kota Surabaya belum menemukan solusi ketika penggusuran tersebut telah dilakukan namun tempat tinggal masyarakat telah dimusnahkan begitu saja. Sebagian masyarakat menetap di jalanan sekitar dua tahun untuk menunggu pembangunan rusunawa di dekat rumah mereka yang digusur setelah rusunawa tersebut sudah bisa ditempati sebagian masyarakat masih menetap ingin tinggal di jalanan tanah mereka yang digusur karena mereka tidak mau mengambil fasilitas dari Pemerintah Kota Surabaya yang telah diberikan kepada masyarakat korban penggusuran. Mereka masih berharap tanahnya untuk kembali dan bisa menempati tanah tersebut hingga sampai saat ini sudah berjalan lima tahun mereka masih memperjuangkan tanahnya dengan cara menetap di jalanan 
sekitar tanah mereka yang dulu digusur dengan bangunan seadanya dan fasilitas yang seadanya secara sangat tidak layak.

\section{KETERLIBATAN DAN PARTISIPASI RAKYAT PADA PEMBANGUNAN KOTA}

Kesadaran rakyat pada proses pembangunan kota merupakan hal terpenting untuk kota tersebut untuk menjadi kota yang lebih baik dan bisa terlepas dari segala permasalahan yang ada di perkotaan. Partisipasi dari rakyat sangat berpengaruh pada pembangunan kota agar pembangunan kotanya tersebut tidak bersifat neoliberalisme. Hal ini sama terjadi di Medokan Semampir Kota Surabaya masyarakat ingin kawasan permukiman kumuh seharusnya diperbaiki secara bersama-sama tidak malah langsung digusur begitu saja. Masyarakat mengaku sanggup untuk memperbaiki kawasan tersebut namun program dari Pemerintah Kota Surabaya tetap harus berjalan yang mengharuskan tempat tinggal masyarakat tersebut harus segera digusur karena untuk mengurangi angka banjir dan kawasan permukiman kumuh di Kota Surabaya.

Keterlibatan masyarakat dalam proses pembuatan kebijakan sangat perlu dibutuhkan karena masyarakat memiliki hak untuk bisa membangun kotanya sendiri menjadi lebih baik. Pembuatan kebijakan tidak boleh jika disetujui oleh beberapa pihak saja namun harus seluruh pihak masyarakat menyetujui kebijakan tersebut agar tidak terjadi komunikasi yang tidak diinginkan oleh masyarakat. Sejalan dengan teori right to the city bahwa masyarakat mempunyai hak untuk dapat mengubah kotanya sendiri menjadi lebih baik (Levebfre, 1967). Maksud dari masyarakat memiliki hak untuk dapat mengubah kotanya sendiri menjadi lebih baik yaitu masyarakat juga ikut terlibat dalam hal pembuatan proses kebijakan masyarakat tidak hanya bisa mengakses fasilitas dari Pemerintah Kota Surabaya saja melainkan masyarakat Medokan juga memiliki hak untuk membenahi tempat tinggal mereka yang dianggap kumuh oleh Pemerintah Kota Surabaya agar tempat tinggal mereka menjadi rumah yang layak huni dan tidak menjadi bangunan liar.

Masyarakat Medokan yang tergusur merasa tidak dilibatkan dalam proses pembuatan kebijakan maupun pembangunan kota bahkan negosiasi yang dilakukan oleh pihak Pemerintah Kota Surabaya mereka tidak menyetujuinya karena disebabkan ganti rugi yang ditawarkan tidak sesuai. Masyarakat juga menolak fasilitas yang diberikan oleh Pemerintah Kota Surabaya karena mereka tetap ingin mempertahankan tanahnya untuk kembali dan alasan lain mereka juga tidak ingin tanah yang dahulu mereka tempati dibangun oleh developer dan pihak swasta. Keterlibatan dalam hal pembangunan kota tersebut sangat penting dilakukan agar kebijakan dan program yang dibuat oleh Pemerintah Kota Surabaya juga diterima oleh masyarakat tidak ada yang merasa diuntungkan salah satu pihak saja namun menguntungkan kedua belah pihak.

Partisipasi rakyat dan kesadaran dari rakyat tentang pentingnya pembangunan kota yang melibatkan masyarakat juga harus kesadaran dari diri sendiri untuk menjadikan kotanya lebih baik. Kesadaran dari masyarakat akan pentingnya pembangunan kota saat ini masih sangat sering diabaikan oleh masyarakat namun ketika Pemerintah Kota Surabaya memiliki program dan kebijakan 
masyarakat baru menyadarinya. Pembangunan kota sangat penting dilakukan agar kota bisa terlepas dari berbagai macam permasalahan yang ada meskipun kota dipandang sebagai tempat tinggal yang buruk namun kota juga dapat melewatnya. Namun ketika ingin mengubah kota menjadi bebas polusi, bebas banjir, bebas dari kemacetan hal tersebut akan menjadi angan-angan saja, hal ini sejalan dengan teori right to the city bahwa kota tidak akan bisa diubah jika ingin terbebas dari banjir, asap kendaraan bermotor, kemacetan dan permasalahan yang lain karena hal tersebut akan menjadi angan-angan saja. Polusi udara, kemacetan, banjir merupakan sifat dasar dari kota sendiri yang tidak akan bisa diubah sifatnya jika diubah maka akan menghilangkan suatu ciri khas dari kota tersebut (Harvey, 2016).

Banyaknya jumlah permukiman kumuh di Kota Surabaya juga merupakan bentuk dari sifat kota itu sendiri karena jumlah penduduk di kota memang sangat padat karena kota merupakan sebagai pusat ekonomi yang dicari oleh masyarakat untuk memiliki kehidupan yang lebih baik. Permukiman kumuh di Kota Surabaya tidak dapat dihilangkan kalaupun jika digusur hal tersebut akan menambah beban negara karena masyarakat yang tergusur akan mendirikan bangunan liar lagi di tempat yang lain sehingga menciptakan kawasan permukiman kumuh yang baru. Program yang diadakan Pemerintah Kota Surabaya dalam pengentasan kawasan prioritas sebaiknya masyarakat diberi kesempatan untuk membenahi dan membangun tempat tinggalnya agar menjadi kawasan permukiman yang layak dan tercipta sanitasi yang sehat pula bukan malah langsung dimusnahkan begitu saja tidak memberikan kesempatan masyarakat dalam hak atas kota tersebut karena hak atas kota hingga sampai saat ini masih sangat sering diabaikan. Masyarakat mengaku jika mereka tidak memiliki hak untuk bisa menyuarakan pendapatnya kepada Pemerintah Kota Surabaya karena mereka ingin tempat tinggal kawasan permukiman kumuh di daerah Medokan Semampir Kota Surabaya dibenahi agar menjadi kawasan permukiman yang layak dan masyarakat juga bersedia jika harus ditegakkan sanksi yang berlaku ketika masyarakat yang lain melanggar peraturan tersebut Rampai, Bunga (2005). Pembangunan Kota Indonesia Dalam Abad 21 Konsep dan Pembangunan Perkotaan di Indonesia. Jakarta: Perpustakaan Nasional RI: Katalog Dalam Terbitan (KDT). Sejalan dengan teori right to the city bahwa masyarakat tidak hanya bisa memanfaatkan sumber daya yang ada di perkotaan namun mereka juga berhak untuk bisa membangun kotanya serta membenahi kotanya agar menjadi kota yang lebih baik.

\section{SIMPULAN}

Upaya Pemerintah Kota Surabaya dalam memenuhi hak atas perumahan yang layak bagi masyarakat korban penggusuran di Medokan Semampir Kota Surabaya sudah berjalan cukup baik namun masih banyak kendala dari Pemerintah Kota Surabaya maupun dari masyarakat Medokan Semampir sendiri. Pemerintah Kota Surabaya telah berupaya membuat program yang dikhususkan untuk masyarakat miskin terutama bagi masyarakat yang terkena dampak penggusuran yang dilakukan dalam pengentasan kawasan prioritas. Pemerintah Kota Surabaya telah berupaya aktif membangun rusunawa karena jumlah penduduk di Kota Surabaya sangat tinggi dan salah satunya juga berupaya 
untuk mengentas kawasan permukiman kumuh di Kota Surabaya agar masyarakat dapat memiliki rumah dengan sanitasi yang sehat yang diharapkan dapat mengentaskan atau mengurangi angka kemiskinan di Kota Surabaya. Namun dalam hal pemenuhan hak atas perumahan yang layak bagi masyarakat korban penggusuran Medokan Semampir mengalami kendala karena masyarakat menolak dengan ganti rugi yang telah ditawarkan oleh Pemerintah Kota Surabaya dan masyarakat juga menolak dengan fasilitas yang telah diberikan oleh Pemerintah Kota Surabaya berupa rumah susun sewa. Hingga masyarakat menetap di sekitar tanah mereka yang digusur membangun bangunan liar lagi, hal tersebut merupakan bentuk protes masyarakat terhadap Pemerintah Kota Surabaya dalam melawan pembangunan kota yang bersifat neoliberalisme (Levebfre, 1967). Masyarakat Medokan menolak dengan adanya program pemerintah tentang pengentasan kawasan prioritas karena mereka merasa dirugikan akibat adanya program Pemerintah Kota Surabaya karena dinilai hanya menguntungkan pihak tertentu saja.

Dampak dari adanya program Pemerintah Kota Surabaya angka banjir dan kawasan permukiman kumuh sudah berkurang namun dampak dari program Pemerintah Kota Surabaya tersebut banyak masyarakat yang kehilangan tempat tinggalnya akibat adanya penggusuran. Menurut Pemerintah Kota Surabaya ruang terbuka hijau dan jumlah oksigen di Kota Surabaya sudah cukup meningkat karena banyak pembangunan taman di tengah kota yang telah dilakukan. Jumlah angka kemiskinan menurut Pemerintah Kota Surabaya sudah berkurang karena masyarakat sudah tidak perlu mengeluarkan banyak biaya untuk berobat hal tersebut dapat mengurangi angka kemiskinan dan masyarakat dapat hidup sehat.

Pemenuhan hak atas perumahan yang layak bagi masyarakat korban penggusuran Medokan Semampir Kota Surabaya sudah berjalan dengan baik namun masih mengalami beberapa macam kendala salah satunya yaitu masyarakat tidak dilibatkan dalam proses pembuatan kebijakan tentang pengentasan kawasan prioritas karena mereka tidak diberi kesempatan untuk membenahi kawasan permukimannya hal ini sejalan dengan teori right to the city bahwa rakyat memiliki hak untuk dapat mengubah kotanya sendiri menjadi lebih baik (Levebfre, 1967). Namun dalam hal penggusuran yang terjadi di Medokan Semampir Kota Surabaya masyarakat merasa tidak dilibatkan dalam proses pembuatan kebijakan. Masyarakat korban dari penggusuran dimaknai tidak semata-mata mereka hanya kehilangan tempat tinggal saja melainkan mereka juga kehilangan hak atas pendidikan untuk anak mereka, hak ekonomi karena kehilangan mata pencaharian, kehilangan hak sosial dan budayanya yang telah dibangun berpuluh puluh tahun lamanya. Penolakan masyarakat atas penggusuran yang dilakukan oleh Pemerintah Kota Surabaya merupakan sebagai bentuk koordinasi dan negosiasi yang tidak baik antara warga dengan Pemerintah sehingga menimbulkan penolakan dari masyarakat karena dirasa hanya menguntungkan pihak tertentu saja. Pemerintah Kota Surabaya terhadap masyarakat korban dari penggusuran hingga sampai saat ini tidak menemukan solusi namun Pemerintah Kota Surabaya telah berupaya untuk memenuhi hak atas perumahan yang layak untuk masyarakat korban penggusuran. 


\section{DAFTAR PUSTAKA}

Adisasmita R (2010) Pembangunan Kawasan dan Tata Ruang. Yogyakarta: Graha Ilmu.

Budihardjo E (2011) Penataan Ruang Pembangunan Perkotaan. Jakarta: Alumni.

David H (2012) Rebel Cities From The Right To The City To The Urban Revolution. Meard Street London: British Library Cataloging.

Levebfre H (1996) Writings On Cities. Cambridge: Blackwell Publishing.

Nuh S (2017) Kebijakan Pembangunan Perkotaan. Malang: UB Press.

Rampai B (2005) Pembangunan Kota Indonesia Dalam Abad 21 Konsep dan Pembangunan Perkotaan di Indonesia. Jakarta: Perpustakaan Nasional RI: Katalog Dalam Terbitan (KDT). 